Food and Agriculture
Organization of the
United Nations

\title{
CHECKLISTS AND TECHNICAL GUIDELINES TO COMBAT ILLEGAL, UNREPORTED AND UNREGULATED (IUU) FISHING
}

Volume I: a consolidated checklist of coastal, flag and port State responsibilities to combat illegal, unreported and unregulated (IUU) fishing

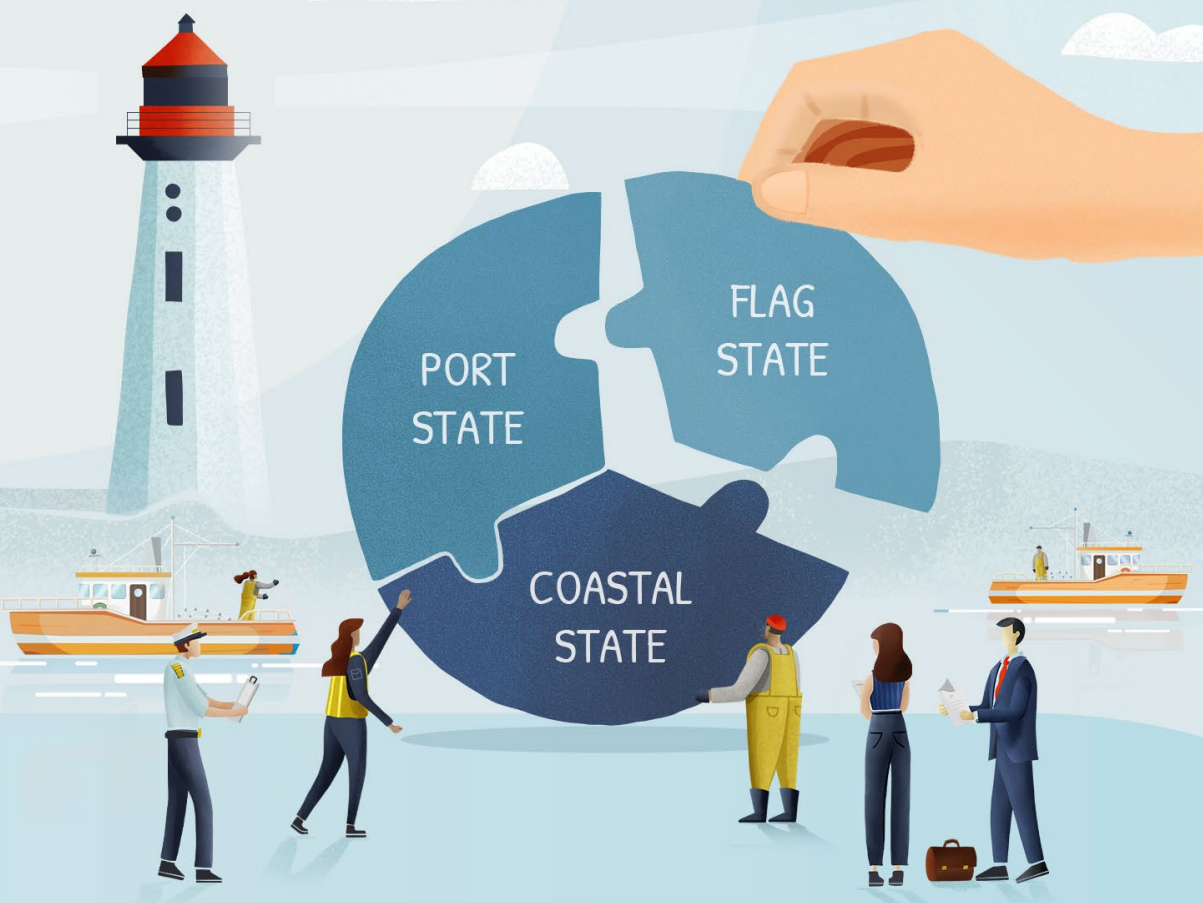





\section{CHECKLISTS AND TECHNICAL GUIDELINES TO COMBAT ILLEGAL, UNREPORTED AND UNREGULATED (IUU) FISHING}

Volume I: a consolidated checklist of coastal, flag and port State responsibilities to combat illegal, unreported and unregulated (IUU) fishing 


\section{Required citation:}

FAO. 2021. Checklists and technical guidelines to combat illegal, unreported and unregulated (IUU) fishing. Volume I: a consolidated checklist of coastal, flag and port State responsibilities to combatillegal, unreported and unregulated (IUU) fishing. Rome. https://doi.org/10.4060/cb5992en

The designations employed and the presentation of material in this information product do not imply the expression of any opinion whatsoever on the part of the Food and Agriculture Organization of the United Nations (FAO) concerning the legal or development status of any country, territory, city or area or of its authorities, or concerning the delimitation of its frontiers or boundaries. The mention of specific companies or products of manufacturers, whether or not these have been patented, does not imply that these have been endorsed or recommended by FAO in preference to others of a similar nature that are not mentioned.

The views expressed in this information product are those of the author(s) and do not necessarily reflect the views or policies of FAO.

ISBN 978-92-5-134781-2

(c) FAO, 2021

\section{(c) (1) (9)}

Some rights reserved. This work is made available under the Creative Commons Attribution-NonCommercialShareAlike 3.0 IGO licence (CC BY-NC-SA 3.0 IGO; https://creativecommons.org/licenses/by-nc-sa/3.0/igo/ legalcode).

Under the terms of this licence, this work may be copied, redistributed and adapted for non-commercial purposes, provided that the work is appropriately cited. In any use of this work, there should be no suggestion that FAO endorses any specific organization, products or services. The use of the FAO logo is not permitted. If the work is adapted, then it must be licensed under the same or equivalent Creative Commons licence. If a translation of this work is created, it must include the following disclaimer along with the required citation: "This translation was not created by the Food and Agriculture Organization of the United Nations (FAO). FAO is not responsible for the content or accuracy of this translation. The original [Language] edition shall be the authoritative edition."

Disputes arising under the licence that cannot be settled amicably will be resolved by mediation and arbitration as described in Article 8 of the licence except as otherwise provided herein. The applicable mediation rules will be the mediation rules of the World Intellectual Property Organization http://www.wipo.int/amc/en/mediation/rules and any arbitration will be conducted in accordance with the Arbitration Rules of the United Nations Commission on International Trade Law (UNCITRAL).

Third-party materials. Users wishing to reuse material from this work that is attributed to a third party, such as tables, figures or images, are responsible for determining whether permission is needed for that reuse and for obtaining permission from the copyright holder. The risk of claims resulting from infringement of any third-partyowned component in the work rests solely with the user.

Sales, rights and licensing. FAO information products are available on the FAO website (www.fao.org/ publications) and can be purchased through publications-sales@fao.org. Requests for commercial use should be submitted via: www.fao.org/contact-us/licence-request. Queries regarding rights and licensing should be submitted to: copyright@fao.org. 


\section{Preparation of this document}

\section{VOLUME I}

This checklist was prepared by the Fisheries Global and Regional Processes Team of FAO's Fisheries Division in collaboration with FAO's Development Law Service. The document was drafted by Adelaida Rey Aneiros, with contributions from Teresa Amador, Sarah Fagnani, Elizabeth Rose Amidjogbe and Marie-Emilie Guele. Overall technical backstopping was provided by Matthew Camilleri, Blaise Kuemlangan and Eszter Hidas.

This checklist is a product of the FAO Global Programme to Support the Implementation of the Agreement on Port State Measures (PSMA) and Complementary International Instruments and Regional Mechanisms to Combat IUU Fishing (hereinafter "the Programme"). 



\section{Contents}

Preparation of this document

Acknowledgements

Abbreviations and acronyms

Executive summary

1. Background

2. Coastal State responsibilities 3

Fisheries management

Record of vessels

Fishing and fishing related activities authorization

Monitoring, control and surveillance (MCS)

Enforcement

3. Flag State responsibilities

Fisheries management

Registration

Record of fishing vessels

Fishing and fishing related activities authorization

Monitoring, control and surveillance (MCS)

Enforcement

4. Port State responsibilities 


\section{Acknowledgements}

Support in the finalisation of this document for publication is gratefully acknowledged, with particular thanks to Edward Fortes for editing, Lorenzo Catena for the cover design and layout, and Marion Pulvano Guelfi for general oversight.

The Fisheries Global and Regional Processes Team is thankful for the generous financial support provided by the Norwegian Agency for Development Cooperation (NORAD), the Swedish Ministry of Foreign Affairs and the European Union. 


\title{
Abbreviations and acronyms
}

\author{
CMMs conservation and management measures \\ adopted by RFMOs \\ FAO Food and Agriculture Organization of the United Nations \\ FAO Global Global Record of Fishing Vessels, Refrigerated Transport \\ Record Vessels and Supply Vessels \\ FMC Fisheries Monitoring Centre \\ FMP Fisheries Management Plan \\ ILO International Labour Organization \\ IMO International Maritime Organization \\ IPOA-IUU International Plan of Action to Prevent, Deter and \\ Eliminate Illegal, Unreported and Unregulated Fishing \\ IUU illegal, unreported and unregulated fishing \\ LOSC United Nations Convention on the Law of the Sea \\ MCS monitoring, control, and surveillance \\ MSY maximum sustainable yield \\ NPOA National Plan of Action \\ PSMA Agreement on Port State Measures to Prevent, Deter and \\ Eliminate IIlegal, Unreported and Unregulated Fishing \\ RFMO/As regional fisheries management \\ organization/arrangements \\ SOPs Standard Operating Procedures \\ TAC total allowable catch \\ VMS vessel monitoring system
}





\section{Executive summary}

The purpose of this document is to aggregate the coastal, flag and port State responsibilities to combat IUU fishing contained in select international fisheries instruments within a single reference document. The responsibilities are presented as a checklist, in questionnaire format. The document aims to serve both as a reference document for professionals as well as an assessment tool for practitioners, in order to facilitate the identification of legal, policy, institutional and operational weaknesses at the national level when implementing coastal, flag and port State responsibilities to combat IUU fishing.

This is the first volume in the series of "Checklists and technical guidelines to combat illegal, unreported and unregulated (IUU) fishing". 



\section{Background}

Illegal, unreported, and unregulated (IUU) fishing remains one of the greatest threats to marine ecosystems, and undermines national and regional efforts to achieve sustainable fisheries. IUU fishing exploits weak management regimes, in particular those of developing countries, which lack the capacity and resources for effective monitoring, control, and surveillance (MCS) of their fisheries, and/or enforcement of their laws and regulations. Products derived from IUU fishing can find their way into overseas trade markets and local food supply chains. IUU fishing also threatens livelihoods, exacerbates poverty and increases food insecurity.

A framework of binding and voluntary international instruments has been developed over recent decades, ${ }^{1}$ which collectively outline the responsibilities of coastal, flag and port States - together with internationally agreed market-related measures - to prevent, deter and eliminate IUU fishing. They provide clear guidance and a powerful suite of tools for States to use to combat IUU fishing. Of these, the 2009 FAO Agreement on Port State Measures (PSMA) is the first binding international agreement to specifically target IUU fishing. If implemented ambitiously, with strong political will and concerted action, this collection of instruments will help States to prevent, deter and eliminate IUU fishing.

In 2017, FAO launched its Global Programme to Support the Implementation of the PSMA and Complementary International Instruments and Regional Mechanisms to Combat IUU Fishing (the Programme), which aims to address the capacity development needs of developing States outlined in Article 21 of the PSMA. The Programme is aligned with Sustainable Development Goal (SDG) 14 of the 2030 UN Agenda for Sustainable Development, particularly SDG 14.4, which calls for an end to overfishing, IUU fishing and destructive fishing practices by 2020. This is to be achieved through, inter alia, capacity building and support for MCS, compliance and enforcement systems.

The primary purpose of the Programme is to provide capacity development initiatives in developing countries, to support States' effective implementation of their coastal, flag and port States responsibilities, in addition to internationally agreed market-related measures to combat IUU fishing. The Programme support includes the provision of technical assistance and training to strengthen national policy and legislative frameworks and enhance national means and competencies to carry out

1 The binding instruments referred to are the 1982 United Nations Convention on the Law of the Sea, the 1993 FAO Compliance Agreement, the 1995 United Nations Fish Stocks Agreement, and the 2009 FAO Agreement on Port State Measures. The voluntary instruments are the 1995 Code of Conduct for Responsible Fisheries, the 2001 International Plan of Action to Combat IUU Fishing, the 2014 Voluntary Guidelines on Flag State Performance, the 2014 Voluntary Guidelines for Securing Sustainable Small-Scale Fisheries, the 2017 Voluntary Guidelines on Catch Documentation Schemes, and the 2019 Voluntary Guidelines on the Marking of Fishing Gear. 
MCS operations to combat IUU fishing. In addition, the Programme supports the development of global information systems and the undertaking of studies and development of practical guidelines and tools to assist in the implementation of the PSMA and complementary international instruments and regional mechanisms.

This checklist is a product of the Programme, with financial support provided by the Norwegian Agency for Development Cooperation (NORAD), the Swedish Ministry of Foreign Affairs, and the European Union. The purpose of the checklist is to aggregate the flag, coastal and port State responsibilities to combat IUU fishing contained in select international fisheries instruments ${ }^{2}$ within a single reference document. Where relevant and appropriate, the checklist also takes into account obligations detailed in other key international instruments, ${ }^{3}$ procedures prescribed by regional fisheries management organizations (RFMOs), as well as case law long established by the International Tribunal for the Law of the Sea (ITLOS). The responsibilities are presented as a checklist, in questionnaire format. The document aims to serve both as a reference document for professionals as well as an assessment tool for practitioners, in order to facilitate the identification of legal, policy, institutional and operational weaknesses at the national level when implementing coastal, flag and port State responsibilities to combat IUU fishing.

This is the first volume in the series of "Checklists and technical guidelines to combat illegal, unreported and unregulated (IUU) fishing".

The next volumes to be published include:

VOLUME II: "A legal checklist of the main duties and responsibilities of coastal, flag and port States, and internationally agreed market-related measures to prevent, deter and eliminate illegal, unreported and unregulated (IUU) fishing", which is intended to be used in the review of national legal frameworks - including primary and secondary fisheries legislation - to ensure full alignment with international instruments.

VOLUME III: "A checklist of monitoring, control and surveillance (MCS) systems, operations, procedures and tools to combat IUU fishing", which is intended to be used for a national MCS review.

2 The United Nations Convention on the Law of the Sea, United Nations Fish Stocks Agreement, FAO Compliance Agreement and FAO Agreement on Port State Measures, Code of Conduct for Responsible Fisheries, International Plan of Action to Combat IUU Fishing, Voluntary Guidelines on Flag State Performance and the Voluntary Guidelines on the Marking of Fishing Gear, have all been considered within these checklists and their provisions are reflected in the questions. This document contains no direct reference to either the Voluntary Guidelines on Catch Documentation Schemes or the Voluntary Guidelines for Securing Sustainable Small-Scale Fisheries.

3 Reference to specific provisions of the IMO Conventions and Protocols along with reference to the 1987 ILO Convention (No.166; ILO, 1987) have been made in this document. General questions relating to the adoption and implementation of the IMO Cape Town Agreement and the ILO Work in Fishing Convention (C188; ILO, 2007) can also be found in these checklists. 


\section{Coastal State responsibilities}

The questions in this Chapter are designed to guide coastal States to exercise rights and responsibilities over persons and vessels and to take measures to ensure that such persons and vessels do not support or engage in IUU fishing, and ensure the conservation and sustainable use of living marine resources in accordance with international law. In exercising their rights and performing their duties in the EEZ, coastal States shall have due regard to the rights and duties of other States. 
Fisheries management

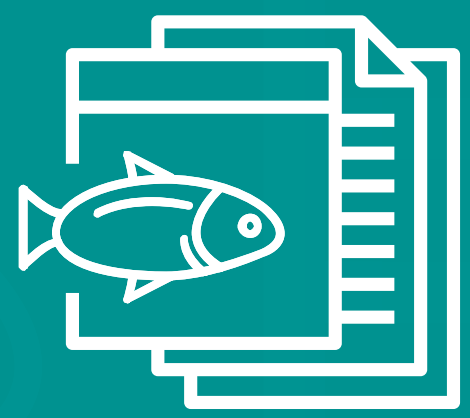


Have you established and implemented an institutional, legal and technical framework for the conservation and management of living marine resources which include, as a minimum:

a. a government authority with a clear mandate and accountability for the results of the conservation and management policy for living marine resources;

b. a government authority to regulate nationals, flagged vessels and foreign vessels operating in areas under your jurisdiction and control, to ensure the conservation and sustainable use of living marine resources; ${ }^{4}$

c. a government authority to ensure the implementation or the transposition into binding domestic law of the international fisheries law and applicable regional fisheries management organization (RFMO) conservation and management measures (CMMs);

d. a government authority responsible for providing scientific advice;

e. a government authority with a mandate to effectively exercise the coastal State's jurisdiction and control in administrative, technical and social matters over vessels under its sovereignty or jurisdiction;

f. a government authority to ensure proper enforcement action on persons and vessels that carry out fishing or fishing related activities in areas under your jurisdiction and control; and

g. the internal organization of agencies to enable inter-agency cooperation and coordination, in particular between fisheries authorities and registry authorities, tax and customs, maritime and port, labour and immigration, health, navy and police?

\section{Have you adopted, implemented and, if applicable, updated a National Plan of Action (NPOA) to prevent, deter and eliminate illegal, unreported and unregulated (IUU) fishing? \\ (}

\begin{tabular}{|l|l} 
Does your legal framework contain a clear set of definitions that ensures terms are used \\
consistently in relation to the Port State Measures Agreement (PSMA), such as "vessel", \\
"fishing" or "fishing related activities"?
\end{tabular}

Does your legal framework on conservation and management of living marine resources include the following elements:

a. personal: all natural and legal persons, nationals and non-nationals including beneficial owners;

b. material: all possible fishing and fishing related activities in administrative, technical and social matters at sea, including those by vessels of other States and stateless vessels, as well as land-based activities; and

c. geographical: all areas under your jurisdiction and control?

4 For these purposes, vessel means: any vessel, ship of another type or boat used for, equipped to be used for, or intended to be used for: a) searching for, attracting, locating, catching, taking or harvesting fish or any activity which can reasonably be expected to result in the attracting, locating, catching, taking or harvesting of fish; or b) any operation in support of, or in preparation for, fishing, including the landing, packaging, processing, transshipping or transporting of fish (including container vessels), as well as the provisioning of personnel, fuel, gear and other supplies at sea.

5 References to "legal framework" in this document include not only fisheries-specific laws and regulations but also other relevant legal texts such as those related to the registration of vessels. 
Have you adopted and implemented fisheries management plan(s) (FMPs) containing CMMs that apply to all areas under your sovereignty or jurisdiction to ensure long-term conservation and sustainable use of living marine resources?

Have you adopted and implemented laws and regulations establishing CMMs that establish or regulate: total allowable catch (TAC), quotas, periods, species, gears, areas, fishing vessel technical characteristics, bycatches, discards, waste, lost or abandoned gear, the protection of juveniles and spawners, landing and transshipment conditions, post-harvesting and trade requirements, etc.?

7 Are these CMMs based on the best available scientific evidence regarding the state of the living marine resources and the possible impact of the aforementioned measures on them?

In the absence of certain, reliable or adequate scientific information, including for new or exploratory fisheries, do you adopt and implement CMMs based on the application of the precautionary approach to protect the living marine resources and preserve the marine environment?

\section{9}

In this latter case, do you have measures in place to ensure that when stock-specific reference points are approached, they will not be exceeded?

Are these CMMs designed to maintain or restore stocks at maximum sustainable yield (MSY) as qualified by relevant environmental and economic factors and considering fishing patterns, the interdependence of stocks and international minimum standards?

Are these CMMs designed to ensure that biodiversity of marine habitats and ecosystems

11 is preserved, that associated or dependent species do not become seriously threatened, endangered species are protected, and that depleted stocks can recover or, where appropriate, are actively restored?

Do these CMMs include, to the extent practicable, the development and use of selective, environmentally safe and cost-effective fishing gear and techniques, designed to ensure that pollution, waste, discards, catch by lost or abandoned gear, catch of non-target species (both fish and non-fish species), and impacts on associated or dependent species are minimized?

13 Have you prohibited dynamiting, poisoning and other comparable destructive fishing practices?

14 Have you established a reliable process to determine your capacity to harvest the living marine resources in areas under your jurisdiction?

Have you adopted and implemented laws and regulations to prevent or eliminate excess

15 fishing capacity and to ensure that levels of fishing effort are commensurate with the sustainable use of fishery resources? 
In those cases where you do not have enough capacity to harvest the entire TAC (and with the objective to promote an optimum utilization of the living marine resources in areas under your jurisdiction), is access to the surplus TAC given through agreements or other arrangements and in compliance with LOSC conditions, to other States? ${ }^{6}$

In the event that you do give persons and vessels of other States access to areas under your jurisdiction in aforementioned case, do you take into account, inter alia:

a. the significance of the area's living resources to the economy of the coastal State and its other national interests;

18

b. the rights of land-locked and geographically disadvantaged States;

c. the requirements of developing States in the subregion or region in harvesting part of the surplus; and

d. the need to minimize economic dislocation in States whose nationals have habitually fished in the zone, or which have made substantial efforts in the research and identification of stocks?

you established and implemented clear obligations for vessels of other States and

19 nationals operating in areas under your jurisdiction and control, including conditions as set out in Article 62.4 of LOSC? (UN, 1982)

Have you established and implemented clear obligations for all States to take measures to ensure that chartered vessels do not engage in IUU fishing, as and when these States are involved in chartering agreements within their respective jurisdictions?

21 Does your legal framework on the conservation and management of living marine resources include updated applicable RFMO CMMs?

Does your legal framework on the conservation and management of living marine resources include updated international principles, rules and standards contained in relevant and applicable international instruments?

Have you established and implemented a legal regime for the conservation and management unjustifiable interference with the rights and freedoms of other States, as provided in LOSC?

With reference to relevant straddling stocks and highly migratory species, have you established formal channels of cooperation with all relevant States - including flag States, and through the establishment or the cooperation with RFMOs or arrangements - to ensure effective conservation and management of those resources and the compatibility of the measures adopted? ${ }^{7}$

25 In adopting CMMs, have you provided that the economic conditions under which fishing industries operate promote responsible fisheries?

26 In adopting CMMs, have you considered the interests of fishers, including those engaged in subsistence, small-scale and artisanal fisheries?

6 As long as both coastal and flag States are satisfied that such activities will not undermine the sustainability of living marine resources within the jurisdiction of the coastal State.

7 In a manner consistent with the rights, competences and interests of the States concerned. 
Do you consult relevant stakeholders during the process of adopting CMMs relating to living marine resources?

Do you ensure that obligations are clearly accessible and communicated to those to whom they apply?

29 Do you provide guidance to the fishing sector to assist them to meet their obligations?

30

Have you established permanent education and training programmes to promote adequate skills for fisheries industry workers?

31

Do you keep records of the crews aboard vessels operating in areas under your sovereignty or jurisdiction? data and information on catch, fishing effort and other fishing related evidence with the States and competent RFMOs concerned, in accordance with applicable international standards and practices, and in sufficient detail to allow sound statistical analysis? 


\subsection{Record of vessels}

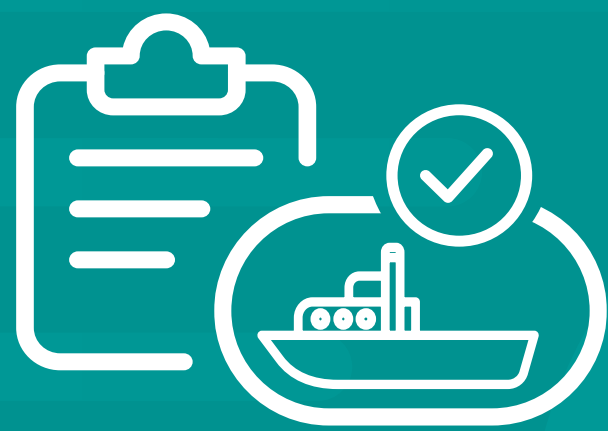

A record of fishing vessels, if established by a coastal State, is not a substitute for a registry of the registration of vessels which the State establishes in its capacity as a flag State. The following minimum requirements apply where there is a decision to establish a record of national and foreign fishing vessels authorized to fish in areas under the jurisdiction of the coastal State. 
Do you have in place a single, complete and updated record with all vessels, including vessels of other States, operating in areas under your jurisdiction and control?

34 Is this record of vessels publicly available and easily accessible (with due regard for appropriate confidentiality requirements)?

Does your legal framework require the following information and data to be contained in the record for each of those vessels flying the flag of other States:

a. name of vessel;

b. registration number;

c. International Maritime Organization (IMO) number if eligible, the same as the Unique Vessel Identifier in the FAO Global Record of Fishing Vessels, Refrigerated Transport Vessels and Supply Vessels (FAO Global Record);

d. port of registry;

e. International Radio Call Sign, if any;

f. name, street address, mailing address and nationality of the natural or legal person in whose name the vessel is registered;

g. name, street address, mailing address and nationality of the natural or legal persons responsible for managing the operations of the vessel, charterer included, if applicable;

h. name, street address, mailing address and nationality of the natural or legal persons with beneficial ownership of the vessel;

i. where and when the vessel was built;

j. characteristics of the vessel:

- type of vessel

- length overall

- moulded depth

- beam

- gross tonnage

- power of main engine or engines, and

- type of fishing method or methods?

k. previous flag, if any;

l. previous names, if any and if known; 
; Continuing "Does your legal framework require..."

m. name and ownership history of the vessel, and, where this is known, the history of non-compliance by that vessel, in accordance with national laws, with CMMs or provisions adopted at a national, regional or global level; and

n. where appropriate, a photograph, taken at the time of registration or at the conclusion of any more recent structural alterations, showing a side profile view of the vessel?

Do the minimum requirements to operate in areas under your jurisdiction and control - and therefore to be included in your record of vessels of other States - include:

a. the 1989 FAO Standard Specifications and Guidelines for Marking and Identification of Fishing Vessels, together with the relevant requirements of the IMO;

b. information on vessel owners and operators, or charterers if applicable, which identifies effective beneficial owners;

c. information on the history of the vessel which identifies prior flag and name changes, as well as its compliance with applicable CMMs;

d. characteristics of the vessel as outlined in question 35 above; and

e. the fulfilment of international requirements and minimum standards in terms of health, safety and working conditions on board the vessel?

Are all the data and information concerning vessels engaged in fishing and fishing related activities in areas under your jurisdiction and control electronically available to all relevant internal competent authorities?

38 Are your competent authorities empowered to cooperate with other States by exchanging information on the registration, deregistration and suspension of registration of vessels?

Are your competent authorities obliged to check the data and information about vessels flying

39 the flag of other States, and requesting to operate in areas under your jurisdiction and control, on the FAO Global Record?

Do you take into account the validity of the vessel navigation permit for fishing or fishing could grant to those vessels?

8 In international instruments "authorization", "license" or "permit" are used as synonyms. However, the most generally used term to refer to the document or permission to carry out fishing or fishing related operations is "authorization". For the purposes of this Checklist, we are using "authorization" in this latter sense. Accordingly, we are using "navigation permit" to refer to the permission usually granted by maritime authorities which allows a vessel to navigate. 
Fishing and fishing related activities authorization

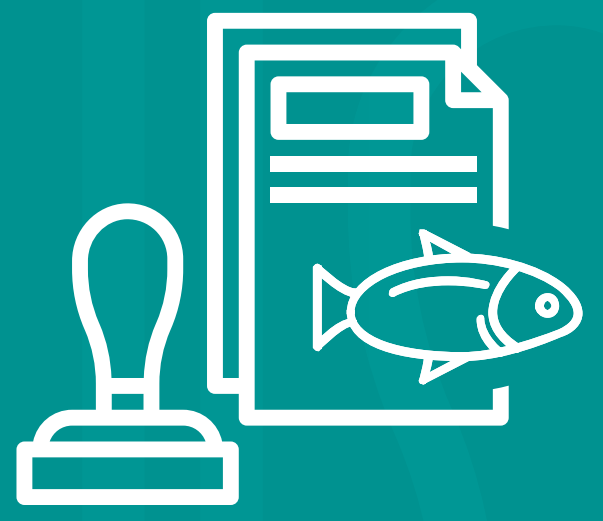


Does your legal framework include a regime to ensure that no fishing or fishing related without an authorization?

42

Does your legal framework clearly designate and empower the competent authority to grant authorizations?

Is it an obligation for the competent authorities that the number and conditions of authorizations, including their duration, do not undermine the sustainability of living marine resources or endanger ecosystems?

Is it a legal requirement for the competent authorities to allow granting an authorization only when jurisdiction and control can be exercised effectively over the vessel to ensure compliance with applicable CMMs, as well as its enforcement jurisdiction and authority over the holder of the authorization?

Is the procedure to request and be granted an authorization public and transparent?

Do the legal requirements to be granted an authorization include:

a. registration number and IMO number if eligible, the same as the Unique Vessel Identifier in the FAO Global Record;

b. a vessel navigation permit, valid throughout the duration of the authorization; ${ }^{9}$

c. positive assessment by the competent authorities that the vessel, including its master, crew, owner and operator (and charterer if applicable), can comply with the terms and conditions of the authorization, ${ }^{10}$ and with the applicable measures, ${ }^{11}$

d. positive assessment by the competent authorities regarding the vessel's and authorization holder's history of compliance; and

e. payment of fees to the National Public Treasurer or its equivalent?

Do the conditions under which an authorization can be issued include:

a. fishing and related logbook keeping;

47

b. navigational equipment to ensure compliance with boundaries and restricted areas for instance;

c. a tamper-proof vessel monitoring system (VMS) functioning according to binding technical specifications

9 Or automatic suspension of the validity of the fishing or fishing related activities authorization if the vessel loses the navigation permit.

${ }^{10}$ For instance, the vessel gear is compatible with the requirements in terms of impacts on juveniles, or the master and crew can fulfil reporting obligations in the official language required, etc.

${ }^{11}$ Including applicable international conventions and national laws and regulations in relation to maritime safety, protections of the marine environment, and conservation and management measures or provisions adopted at a national, regional or global level. 


\section{; Continuing "Do the conditions under..."}

d. catch recording and timely reporting conditions on catch, effort, discards, fishing location, date and time fished, etc.;

e. marking of the vessel in accordance with internationally recognized standards such as the 1984 FAO Standard Specification and Guidelines for the Marking and Identification of Fishing Vessels;

f. marking of fishing gear in accordance with internationally recognized standards, such as the 2019 FAO Voluntary Guidelines for the Marking of Fishing Gear;

47

g. transshipment conditions, where applicable, such as authorization requests and reporting:12

h. observer coverage if applicable;

i. for vessels engaged in fishing related activities, the prohibition to grant services to or engage with vessels engaged in IUU fishing activities;

j. for vessels of other States, the obligation to comply with your laws and regulations as well as with subregional, regional or global measures, where applicable?

Does your authorization regime require information enabling the identification of accountable persons, areas and species to be reflected in the authorization itself, including:

a. name of the vessel;

b. IMO number (if eligible; same as Unique Vessel Identifier in the FAO Global Record);

c. natural or legal person authorized to engage in fishing and fishing related activities;

d. the areas, scope and duration of the authorization;

e. the species, fishing gear authorized, and other applicable CMMs?

49 Is the authorization cancelled when the vessel is de-registered?

Do you promote the development of appropriate standards and guidelines which would

50 lead to the more efficient use of energy in harvesting and post-harvest activities within the fisheries sector?

51 Do you promote the development and transfer of technology in relation to energy optimization within the fisheries sector?

12 Including: date and location; weight by species and catch area; name, registration, flag and other relevant information related to the vessels involved in the transshipment to ensure its legality, together with the port of landing of the transshipped catch. 
Monitoring, control and surveillance (MCS)

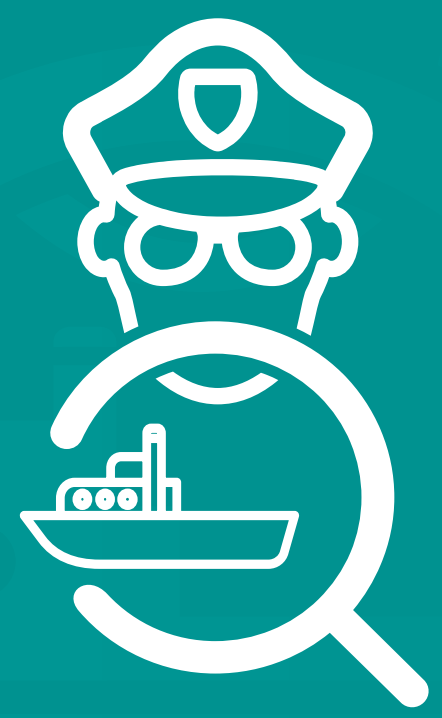


53

Does your legal framework include an effective MCS system for fishing and fishing related activities to ensure compliance with your CMMs, as well as those adopted by RFMOs?

54 Does the scope of your MCS system apply to all vessels in areas under your jurisdiction?

55

Does the scope of your MCS system apply to all fishing and fishing related activities at sea and on land?

56

Does the scope of your MCS system apply to all natural and legal persons under your jurisdiction?

57 Have you clearly determined all relevant authorities and their roles and responsibilities within the MCS system?

58 Are these authorities protected, empowered and accountable in the exercise of their MCS responsibilities?

Do MCS institutions have the staff and a budget proportionate to the size of the areas under

59 your sovereignty and jurisdiction, as well as to the fishing and fishing related fleet operating within them?

60 Do MCS authorities acquire, store and exchange MCS relevant data and information as required (with due regard for the appropriate confidentiality requirements)?

$\bigcirc$

61 Do MCS authorities have access to the up-to-date record of vessels?

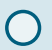

62 Do MCS authorities regularly check the FAO Global Record?

Do MCS authorities regularly and timely exchange information with other States, ${ }^{13} \mathrm{RFMOs,}$

63 FAO and other relevant international organizations in line with PSMA requirements for port and flag States?

64

Do MCS authorities use international standards in the exchange of information, including the ones in Annex D ("Information systems on port State measures") of the PSMA?

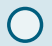

65 Do MCS authorities have access to relevant information under the competence of other agencies such as maritime, customs, ports, health, navy etc.?

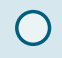
Have you adopted a National Plan of Control and Inspection based on risk analysis (including
66 at the regional level, if applicable), to ensure the proper implementation and compliance with applicable CMMs?

67 Does your National Plan of Control and Inspection apply to all fishing and fishing related activities at sea and on land including transport and processing plants? 
68 Have you adopted Standard Operating Procedures (SOPs) and handbooks for the different actions to be carried out under the National Plan of Control and inspection?

Do you have in place a 24/7 operational Fisheries Monitoring Centre (FMC) receiving VMS signal from tamper-proof devices installed in all vessels operating in areas under your sovereignty and jurisdiction or other Information Technology monitoring solutions for small vessels, artisanal fleet and subsistence vessels?

70 Have you established a legally binding time frequency with which vessel transponders shall transmit VMS signals such as position, speed, etc.?

71 Are tracking records and reports from the FMC legally acceptable evidence in administrative and criminal procedures?

Are vessels masters obliged to use other means to transmit their position and speed in case of

72 VMS failure? If so, do you consider as reasonable the duration of the use of other means before the failure must be addressed? \begin{tabular}{l|l}
73 & $\begin{array}{l}\text { Are vessels not transmitting VMS signal obliged to go to a port when the system cannot be } \\
\text { fixed at sea? }\end{array}$
\end{tabular}

74 Have you adopted and implemented SOPs and handbooks for staff in the FMC?

75 Is the staff at the FMC properly trained in risk assessment and able to identify suspicious patterns, encounters, possible IUU fishing operations, etc.?

Do the staff at the FMC have access to all relevant data and information on the vessels such as registration, fishing or fishing related authorizations, previous inspection reports, vessels ranked by risk, etc.?

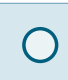

Have you attributed legal authority to your competent authorities to take control of any

77 fishing or fishing related vessel in areas under your jurisdiction, including the denial of sailing and recall to port?

Have you established mandatory requirements regarding fisheries-related data that must be recorded and reported in a timely manner by the vessels/masters/operators? (This includes logbooks, catches, effort, bycatches and discards, storage plans, landing declarations, transshipments, ${ }_{1}^{14}$ sales notes, etc.)

79 Have you established the frequency for that mandatory data transmission, and how, by whom and to whom it will be transmitted? 
81 Do you have national or regional observer programmes in place to monitor and verify the reported catch of target and non-target species?

82 Have you clearly defined the objectives and tasks of the observer on board as well as established effective measures to ensure their safety?

83 Have you established how the mandatory observer report will be transmitted and the frequency of its transmission?

84 Is the observer report legally acceptable evidence in administrative and criminal proceedings?

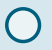

85

Do you oblige vessels operating in areas under your jurisdiction to land, transship or use other port services only in PSMA-designated ports?

Do you have in place risk-based inspection schemes, including SOPs and handbooks, for processing?

Have you established benchmarks in those inspection schemes, including how to adjust those number of violations detected?

89 Is the vessel port inspection procedure in line with Annex B ("Port State inspection procedures") of the PSMA ${ }^{15}$

90 Is the content of the inspection report in line with Annex C ("Report of the results of the inspection") of the PSMA?

Have you established minimum training requirements for all staff involved in MCS activities,

91 including those described for port State inspectors in Annex E ("Guidelines for the training of inspectors") of the PSMA?

Is it an obligation for masters and crews on vessels and operators of fishing and fishing related activities, to cooperate during inspections and produce all documents as required by the inspector or competent authority on vessel position, catches, fishing gear, fishing operations and related activities?

93 Are the State inspection reports legally acceptable evidence in administrative and criminal proceedings? implement joint MCS actions? 
Do you implement internationally agreed MCS measures, adopted in the framework of a competent RFMO and consistent with international law, to deter the activities of vessels which are flying the flag of non-cooperating non-contracting parties to that RFMO/arrangement and which engage in activities which undermine the effectiveness of CMMs of such an RFMO/A?

96 Do you carry out awareness-raising campaigns directed at the industry to promote compliance and a better understanding of MCS requirements?

97 Do you promote knowledge and understanding of MCS issues within national judicial and administrative systems? 
2.5 Enforcement

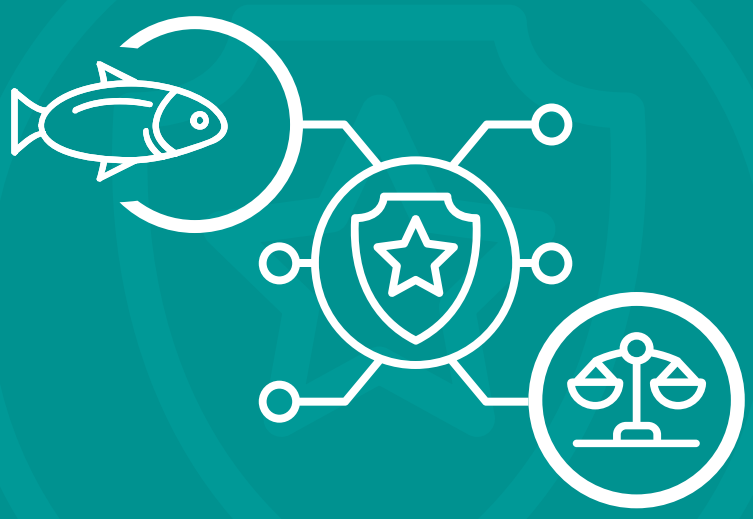


Does your legal framework include a proportionate and effective enforcement regime to deter and respond to violations of your CMMs concerning fishing and fishing related activities, as well as those adopted by competent RFMOs?

Does your legal system clearly define what actions or omissions will be considered as a violation?

Does your legal framework establish which of those violations will be considered as serious, including: falsifying markings, and/or the identity or registration of a vessel; operating without a vessel navigation permit or a fishing authorization; operating in violation of the conditions set out in the authorization; not accurately recording, not reporting or seriously misreporting catch or catch-related data; obstructing, concealing, tampering with or disposing of evidence relating to an investigation; committing several non-serious violations; other violations considered serious under competent RFMOs, etc.?

101 Does your legal framework clearly establish who is to be accountable for any violation, including the owner, beneficial owner, operator, charterer, master, etc.?

102 Do you have the capacity to detect and take enforcement action with respect to violations?

103 Do you have the authority and capacity to conduct timely investigations of violations, including the establishment of the identity of the offenders and the nature of the violations?

Does your legal framework include the obligation to investigate and, if appropriate, take necessary action, upon the receipt of a report from a third country or RFMO, with clear grounds that proper jurisdiction and control have not been exercised over a vessel under your jurisdiction or that it has been identified as participating in IUU fishing or fishing related activities in support of such fishing?

Do you have an appropriate system in place for the diligent acquisition, collection, preservation of evidence and maintenance of its integrity, including by making it available to enforcement authorities of other States and, if applicable, to RFMOs?

Do you have an administrative or criminal legal framework in place to ensure that procedures to apply sanctions are initiated in a timely and effective manner against those who act in contravention of your legal framework?

Do you have in your legal framework a regime of sanctions proportionate to the seriousness of the violation, which deprive offenders of the benefits accruing from their illegal activities and are effective in securing compliance and discouraging violations wherever they occur?

Does your sanction regime include the refusal, suspension or withdrawal of vessel authorizations for serious violations?

Does your sanction regime include the refusal, suspension or withdrawal of economic incentives, including subsidies, for legal or natural persons and vessels that committed violations? 
Does your sanction regime include the prohibition of high seas fishing and fishing related activities where a vessel has been involved in the commission of a serious violation, until such time that the outstanding sanctions imposed have been complied with?

Does your sanction regime include provisions which may permit, inter alia, refusal, withdrawal

111 or suspension of authorizations to serve as masters or officers of a vessel where such masters or officers hold national authorizations?

Does your enforcement scheme establish specific sanctions for those who obstruct the task of the duly authorized inspectors, observers, authorized persons or officials of other competent authorities?

Does your enforcement scheme establish specific sanctions for those competent authorities who do not carry out their duties with due diligence?

Is your enforcement scheme capable of ensuring that sanctions are complied with including, where appropriate, preventing the vessel and the natural or legal person from engaging in fishing or fishing related activities while proceedings take place and after sanctions are complied with?

Does your enforcement scheme grant the power to your competent authorities to impose immediate enforcement measures such as detention, confiscation, denial of the use of port services, or any other measure needed to ensure that the suspected IUU-derived products do not reach the market while the investigation is ongoing?

Does your sanction regime establish specific and more severe sanctions in cases of repeated offences?

Does your enforcement scheme establish the obligation for your competent authorities to engage in cooperation and mutual legal assistance, including, as appropriate, the sharing of information and reporting arrangements with other States and international organizations including RFMOs, as well as the timeliness of action following requests for assistance?

Do you implement effective and timely sanctions in response to requests from other States or, if applicable, RFMOs to take measures concerning vessels in areas under your jurisdiction?

Do you contribute to the establishment of regional schemes for cooperation with other States and RFMOs in the enforcement of applicable measures with respect to fishing operations and fishing related activities?

Do you contribute in the implementation with other States and RFMOs of joint enforcement efforts of applicable measures with respect to fishing operations and fishing related activities?

Do you implement internationally agreed enforcement measures, adopted in the framework of a competent RFMO and consistent with international law, to deter the activities of vessels who are flying the flag of non-cooperating non-contracting parties to that RFMO/arrangement and which engage in activities which undermine the effectiveness of CMMs of such an RFMO? 
122

Have you made arrangements individually, together with other States or with the appropriate international organization to integrate fishing operations into maritime search and rescue systems?

123

Do vessels and crews arrested due to violations of LOSC have the right to be promptly released upon the posting of a reasonable bond or other security?

Do penalties for violations of your fisheries laws committed in areas under your jurisdiction

124 not include imprisonment or any other form of corporal punishment, in the absence of agreements to the contrary with the States concerned? 



\section{Flag State responsibilities}

The questions in this Chapter are designed to guide flag States to exercise jurisdiction and control over their vessels effectively, take measures to ensure that persons subject to their jurisdiction do not support or engage in IUU fishing, and ensure responsibility for the conservation and sustainable use of living marine resources in accordance with international law, national sovereignty and, in respect of the high seas, with due regard to the interests of other States. 


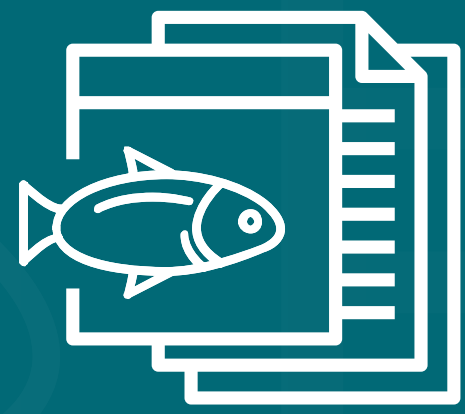


Have you established an institutional, legal and technical framework for the conservation and management of marine living resources which include, as a minimum: ${ }^{16}$

a. a government authority with a clear mandate and accountability for the results of the conservation and management policy for living marine resources;

b. a government authority to issue regulations for nationals and flagged vessels to ensure the conservation and sustainable use of living marine resources; ${ }^{17}$

c. a government authority to ensure the implementation or the transposition into binding domestic law of the international fisheries law, in addition to the CMMs issued by the

125 applicable RFMO;

d. a government authority for scientific advice;

e. a government authority to exercise its jurisdiction and control effectively in administrative, technical and social matters over vessels flying its flag in waters under its sovereignty or jurisdiction, on the high seas and in other State waters, and exercising due diligence; ${ }^{-18}$

f. a government authority to ensure proper enforcement action on nationals and flagged vessels that carry out fishing or fishing related activities; and

g. an internal organization for inter-agency cooperation and coordination, in particular between fisheries authorities and registry authorities, tax and customs, maritime and port, labour and immigration, health, navy and police?

Have you adopted, implemented and, if applicable, updated a National Plan of Action (NPOA) to prevent, deter and eliminate IUU fishing?

Does your legal framework contain a clear set of definitions that ensures terms are used in consistency with the Port State Measures Agreement (PSMA), such as "vessel", "fishing" or "fishing related activities"? 19

Does your legal framework on the conservation and management of living marine resources include the following elements:

a. personal: all natural and legal persons subject to flag State jurisdiction, including its nationals and, where appropriate, stateless vessels;

b. material: all possible fishing and fishing related activities in administrative, technical and social matters;

c. geographical: all areas where your flagged vessels operate and in fulfilment of the flag State's due diligence including the high seas and areas under the jurisdiction and control of other States?

${ }^{16}$ All the responsibilities listed for government authorities may be exercised by the same government authority as long as it is authorized to do so.

17 For these purposes "vessel" means: any vessel, ship of another type or boat used for, equipped to be used for, or intended to be used for: a) searching for, attracting, locating, catching, taking or harvesting fish, or any activity which can reasonably be expected to result in the attracting, locating, catching, taking or harvesting of fish; or, b) any operation in support of, or in preparation for, fishing, including the landing, packaging, processing, transshipping or transporting of fish (including container vessels), as well as the provisioning of personnel, fuel, gear and other supplies at sea.

18 Acting as a coastal State in this case.

19 References in this document to "legal framework" include not only fisheries-specific laws and regulations but also other relevant legal instruments such as those regulating the registration of vessels. 


\section{9}

Have you adopted and implemented fisheries management plan(s) (FMPs) containing CMMs that apply to all flagged vessels and nationals to ensure long-term conservation and the sustainable use of living marine resources?

$130 \begin{aligned} & \text { Have you adopted and implemented laws and regulations establishing CMMs that regulate } \\ & \text { total allowable catch (TAC), quotas, periods, species, gears, areas, fishing vessel technical } \\ & \text { characteristics, bycatches, discards, waste, lost or abandoned gear, the protection of juveniles } \\ & \text { and spawners, landing and transshipment conditions, post-harvesting and trade requirements, } \\ & \text { etc.? }\end{aligned}$

131

Are these CMMs based on the best available scientific evidence regarding the state of the living marine resources and the possible impact of the aforementioned measures on them?

In the absence of certain, reliable or adequate scientific information, including for new or exploratory fisheries, have you adopted and implemented CMMs based on the application of the precautionary approach to protect the living marine resources and preserve the marine environment?

133 In this latter case, do you have measures in place to ensure that when stock-specific reference points are approached, they will not be exceeded?

Are these CMMs designed to maintain or restore stocks at MSY as qualified by relevant environmental and economic factors and considering fishing patterns, the interdependence of stocks and international minimum standards?

Are these CMMs designed to ensure that biodiversity of marine habitats and ecosystems is preserved, associated or dependent species do not become seriously threatened, endangered species are protected, and depleted stocks can recover or, where appropriate, are actively restored?

Do these CMMs include, to the extent practicable, the development and use of selective, environmentally safe and cost-effective fishing gear and techniques, designed to ensure that pollution, waste, discards, catch by lost or abandoned gear, catch of non-target species (both fish and non-fish species), and impacts on associated or dependent species are minimized?

137 Have you prohibited dynamiting, poisoning and other comparable destructive fishing practices?

Have you adopted and implemented laws and regulations to prevent or eliminate excess fishing capacity and to ensure that levels of fishing effort are commensurate with the sustainable use of fishery resources?

Have you adopted and implemented laws and regulations to avoid conferring economic support, including subsidies, to legal or natural persons and vessels involved in IUU fishing or causing overfishing? in IUU fishing? 
141

Does your legal framework on fisheries management include updated applicable RFMO CMMs?

Does your legal framework on the conservation and management of living marine resources

142 include updated international principles, rules and standards contained in relevant and applicable international instruments?

With regard to any living marine resources exploited by your flag vessels in high seas areas, and in particular for straddling stocks and highly migratory species, have you established formal channels of cooperation with all relevant States, such as coastal States, and through the establishment or the cooperation with RFMOs or arrangements, to ensure effective conservation and management of those resources and the compatibility of the measures adopted?20

144 In the adoption of CMMs, have you provided that the economic conditions under which fishing industries operate promote responsible fisheries?

In the adoption of CMMs, have you considered the interests of fishers, including those engaged in subsistence, small-scale and artisanal fisheries?

146 Do you consult relevant stakeholders during the process of adoption of CMMs relating to living marine resources?

147 Do you ensure that the obligations are clearly accessible and communicated to those to whom they apply?

148 Do you provide guidance to the fishing sector to assist them to meet their obligations?

149 Have you established permanent education and training programmes to ensure adequate skills of captains and crews, including through the granting of competency certificates?

150 Do you keep records of the crews of your flagged vessels?

Do you collect, maintain, update, verify, compile and exchange with concerned States and competent RFMOs timely, complete and reliable data and information on catch, fishing effort and other fishing related evidence, in accordance with applicable international standards and practices, and in sufficient detail to allow sound statistical analysis?

Have you carried out a performance assessment of your conservation and management policy for living marine resources, as well as your performance as a flag State generally, in line with the 2015 FAO Voluntary Guidelines for Flag State Performance (VGFSP)? 
3.2 Registration

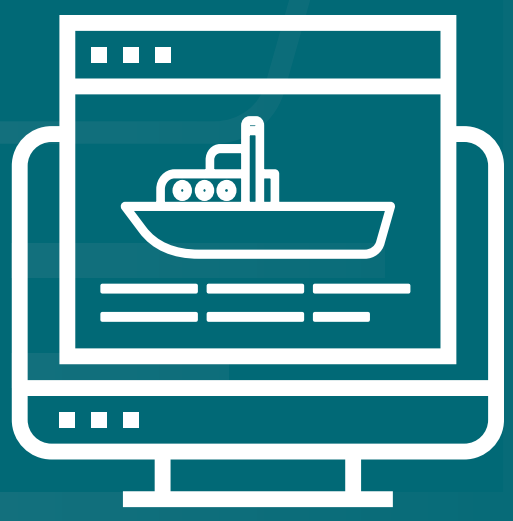


153

Do you have a single, complete and updated registry in place, which includes all of your flagged vessels?

Are your flag vessels data publicly available and easily accessible with due regard for appropriate confidentiality requirements?

Does your legal framework require the registry for each of your flagged vessels to contain the following information and data:

a. name of vessel;

b. registration number;

c. IMO number, if eligible; same as Unique Vessel Identifier in the FAO Global Record;

d. port of registry;

e. International Radio Call Sign, if any;

f. name, street address, mailing address and nationality of the natural or legal person in whose name the vessel is registered;

g. name, street address, mailing address and nationality of the natural or legal persons responsible for managing the operations of the vessel, charterer included, if applicable;

h. name, street address, mailing address and nationality of natural or legal persons with beneficial ownership of the vessel;

i. where and when the vessel was built;

155

j. characteristics of the vessel:

- type of vessel

- length overall

- moulded depth

- beam

- gross tonnage

- power of main engine or engines, and

- type of fishing method or methods;

k. previous flag, if any;

I. previous names, if any and if known;

m. name and ownership history of the vessel and, where this is known, the history of

non-compliance with CMMs or provisions adopted at a national, regional or global level by that vessel, in accordance with national laws; and

n. where appropriate, a photograph, taken at the time of registration or at the conclusion of any more recent structural alterations, showing a side profile view of the vessel? 
Is the registration authority a public, governmental entity empowered with sovereign State competence to grant nationality and flag to a vessel?

Do the minimum requirements in respect of the registration of a vessel include:

a. the 1989 FAO Standard Specifications and Guidelines for Marking and Identification of Fishing Vessels and relevant requirements of the IMO;

b. information on vessel owners and operators, or charterers if applicable, which identifies

157 effective beneficial owners;

c. information on the history of the vessel which identifies prior flag and name changes;

d. characteristics of the vessel; and

e. fulfilment of international requirements and minimum standards in terms of health, safety and working conditions on board the vessel?

Does the legal procedure to register a vessel include:

a. verification of vessel records and history, including through consultation with prior flag States, ${ }^{21}$

b. coordination of registration between relevant agencies - such as fisheries and maritime authority - including through a previous consultation with fisheries authorities to ensure that the vessel will be granted a fishing authorization if flagged; $; 2$

c. grounds for refusal of registration of the vessel, including if the vessel is on an IUU fishing vessel list or record, ${ }^{23}$ or its fishing/fishing related activities authorization has been withdrawn within the last three years, or is registered in two or more States, or still holds a registration from another State and it is not a case of temporary parallel registration;

d. granting a Certificate of Registry, which the operator of the vessel is obliged to ensure is carried on board at all times;

21 To determine whether there are pending investigations or sanctions that may provide a motive for flag hopping: in other words, the practice of repeated and rapid changes of a vessel's flag for the purposes of circumventing CMMs or provisions which have been adopted at a national, regional or global level, or of facilitating noncompliance with such measures or provisions.

22 In international instruments "authorization", "license" or "permit" are used as synonyms. However, the most generally used term to refer to the document or to the permission to carry out fishing or fishing related operations is "authorization". For the purposes of this checklist, we are using "authorization" in this latter sense. Accordingly, the term "navigation permit" is used to refer to the permission usually granted by maritime authorities allowing a vessel to sail.

${ }^{23}$ Unless the ownership of the vessel has subsequently changed and the new owner has provided sufficient evidence demonstrating that the previous owner or operator has no further legal, beneficial or financial interest in, or control of, the vessel, or having taken into account all relevant facts, it determines that flagging the vessel would not result in IUU fishing or fishing related activities in support of such fishing. 
i Continuing "Does the legal procedure..."

e. notification of changes and regular update requirements;

f. deregistration requirements, such as the completion of pending investigations or the settlement of imposed sanctions; and

g. deregistration causes, such as having the fishing authorization withdrawn, scrapping, failing to pass a regular inspection on the condition of the vessel and thereby failing to get the vessel navigation permit?

160

Do you require specific conditions to fulfil your obligation to ensure the essential, genuine link between the vessel and your country?

161

Are all the data and information regarding vessels engaged in fishing and fishing related activities electronically available to all relevant internal competent authorities?

Are your competent authorities empowered to cooperate with other States by exchanging information on the registration, deregistration and suspension of registration of vessels?

Are your competent authorities obliged to maintain the data and information on registration, deregistration and suspension of registration of vessels in accordance with relevant subregional, regional and international standards and requirements, including those from RFMOs?

Are your competent authorities obliged to upload and maintain updated the data and information about your flagged vessels on the FAO Global Record?

\section{○}

Is it compulsory for your flagged vessels to pass a regular inspection by the competent authorities on the technical conditions of the vessel?

Is the validity of the vessel navigation permit for fishing or fishing related activities coordinated with the validity of any specific fishing authorization?

Is it an obligation, under your legal framework, for owners or charterers of vessels to carry sufficient insurance cover to protect their crews and their interests, to indemnify third parties against loss or damage and to protect their own interests?

Have you promoted access to insurance coverage for owners and charterers of vessels?

Are crew members on board your flagged vessels entitled to repatriation, taking account

of the principles laid down in the 1987 ILO Repatriation of Seafarers Convention (Revised), (No.166)?

Have you established obligations to ensure that fishing and fishing related activities are conducted with due regard to the safety of human life and the 1972 IMO International Regulations for Preventing Collisions at Sea, as well as IMO requirements relating to the organization of marine traffic (IMO, 1965), the prevention of pollution (IMO, 1973), the protection of the marine environment and the prevention of damage to or by lost, abandoned or otherwise discarded fishing gear? 
172 Has your country ratified and implemented the IMO Cape Town Agreement (IMO, 2018)?

Do you encourage the development of appropriate standards and guidelines which would

173 lead to the more efficient use of energy in harvesting and post-harvest activities, as well as reducing the emission of ozone-depleting substances in your fisheries fleet?

Do you encourage the development and transfer of technology in relation to energy

174 optimization within your fisheries fleet and, in particular, encourage owners, charterers and managers of fishing vessels to fit energy optimization devices to their vessels?

Are fishing vessels or fishing support vessels required by banks and financial institutions, as a condition of a loan or mortgage, to not be flagged to a State different from the beneficial ownership, where such a requirement would increase the likelihood of non-compliance with international CMMs? 


\section{Record of}

fishing vessels

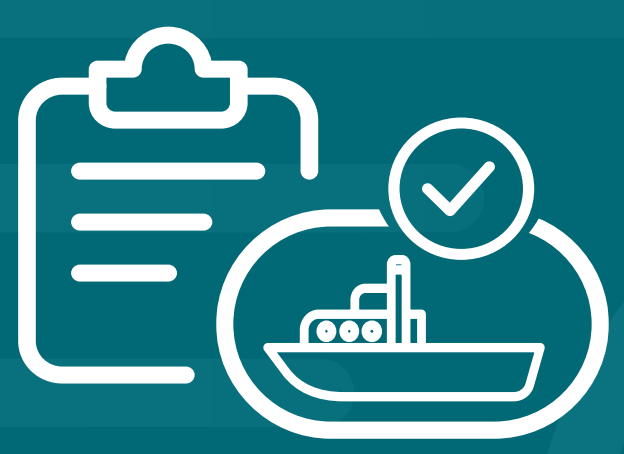

A record of fishing vessels is not a substitute for a registry of the registration of vessels. The following minimum requirements apply where there is a decision to establish a record of fishing vessels separately from the process of vessel registration (which grants nationality to a vessel) or where fishing vessels of certain characteristics are exempt from registration. 
Do you have in place a single, complete and updated record of fishing vessels, including fishing vessels of other States operating under your jurisdiction and control?

\section{Does your legal framework require, as a minimum, the following information and data in} respect of each vessel which should be contained in the record of fishing vessels:

a. name of vessel;

b. registration number;

c. IMO number, if eligible; same as Unique Vessel Identifier in the FAO Global Record;

d. port of registry;

e. International Radio Call Sign, if any;

f. name, street address, mailing address and nationality of the natural or legal person in whose name the vessel is registered;

g. name, street address, mailing address and nationality of the natural or legal persons responsible for managing the operations of the vessel, charterer included, if applicable;

h. name, street address, mailing address and nationality of natural or legal persons with beneficial ownership of the vessel;

i. where and when the vessel was built;

j. characteristics of the vessel:

\begin{tabular}{|l|c|}
\hline - type of vessel & $\bigcirc$ \\
\hline - length overall & $\bigcirc$ \\
\hline - moulded depth & $\bigcirc$ \\
\hline - beam & $\bigcirc$ \\
\hline - gross tonnage & $\bigcirc$ \\
\hline - power of main engine or engines, and & $\bigcirc$ \\
\hline - type of fishing method or methods & $\bigcirc$ \\
\hline \begin{tabular}{l} 
k. previous flag, if any; \\
\hline $\begin{array}{l}\text { l. previous names, if any and if known; } \\
\text { mon- name and ownership history of the vessel, and, where this is known, the history of } \\
\text { adopted at a national, regional or global level; and }\end{array}$
\end{tabular} \\
\hline $\begin{array}{l}\text { n. where appropriate, a photograph, taken at the time of registration or at the conclusion of } \\
\text { any more recent structural alterations, showing a side profile view of the vessel? }\end{array}$ & $\bigcirc$ \\
\hline
\end{tabular}




\begin{tabular}{|c|c|}
\hline \multirow{6}{*}{179} & $\begin{array}{l}\text { Do the minimum requirements to operate in areas under your jurisdiction and control - and } \\
\text { therefore to be included in your record of fishing vessels of other States - include: }\end{array}$ \\
\hline & $\begin{array}{l}\text { a. the } 1989 \text { FAO Standard Specifications and Guidelines for Marking and Identification of } \\
\text { Fishing Vessels, together with the relevant requirements of the IMO; }\end{array}$ \\
\hline & $\begin{array}{l}\text { b. information on fishing vessel owners and operators, or charterers if applicable, which } \\
\text { identifies effective beneficial owners; }\end{array}$ \\
\hline & $\begin{array}{l}\text { c. information on the history of the fishing vessel which identifies prior flag and name changes, } \\
\text { as well as its compliance with applicable CMMs; }\end{array}$ \\
\hline & d. characteristics of the vessel as outlined in question 178 above; and \\
\hline & $\begin{array}{l}\text { e. the fulfilment of international requirements and minimum standards in terms of health, } \\
\text { safety and working conditions on board the fishing vessel? }\end{array}$ \\
\hline 180 & $\begin{array}{l}\text { Are all the data and information concerning vessels engaged in fishing and fishing related } \\
\text { activities in areas under your jurisdiction and control electronically available to all relevant } \\
\text { internal competent authorities? }\end{array}$ \\
\hline 181 & $\begin{array}{l}\text { Are your competent authorities empowered to cooperate with other States by exchanging } \\
\text { information contained in the record of fishing vessels including information on the } \\
\text { registration, deregistration and suspension of registration of vessels? }\end{array}$ \\
\hline 182 & $\begin{array}{l}\text { Are your competent authorities obliged to check the data and information in the record of } \\
\text { fishing vessels about vessels flying the flag of other States, and requesting to operate in areas } \\
\text { under your jurisdiction and control, on the FAO Global Record? }\end{array}$ \\
\hline 183 & $\begin{array}{l}\text { Do you take into account the validity of the vessel navigation permit for fishing or fishing } \\
\text { related activities in order to align the validity of any specific fisheries authorization that you } \\
\text { could grant to those vessels? }{ }^{24}\end{array}$ \\
\hline 184 & $\begin{array}{l}\text { Is the record of fishing vessels required to include information in (178) above of fishing vessels } \\
\text { that are not authorized to fish on the high seas (IPOA-IUU para 43)? }\end{array}$ \\
\hline
\end{tabular}

\footnotetext{
${ }^{24}$ In international instruments "authorization", "license" or "permit" are used as synonyms. However, the most generally used term to refer to the document or permission to carry out fishing or fishing related operations is "authorization". For the purposes of this Checklist, we are using "authorization" in this latter sense. Accordingly, we are using "navigation permit" to refer to the permission usually granted by maritime authorities which allows a vessel to navigate.
} 
Fishing and fishing related activities authorization

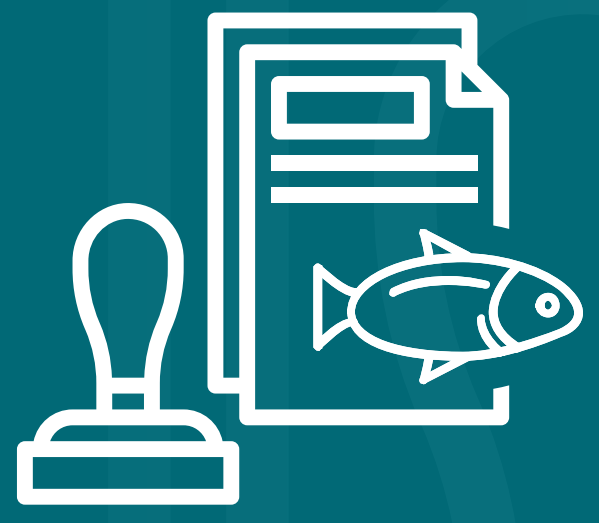


Does your legal framework include a regime to ensure that no fishing or fishing related activities by your flagged vessels are carried out without an authorization, including on the high seas and in other States' waters?

186 Does your legal framework clearly designate and empower the competent authority to grant authorizations?

Is it an obligation for the competent authorities that the number and conditions of an authorization, including its duration, do not undermine the sustainability of the living marine resources or endanger ecosystems?

Is it a legal requirement for the competent authorities to grant an authorization only when they can effectively exercise jurisdiction and control over the vessel to ensure compliance with applicable CMMs, its enforcement jurisdiction, and authority over the holder of the authorization?

Do the legal requirements to be granted an authorization include:

a. registration number and IMO number, if eligible, the same as the Unique Vessel Identifier in the FAO Global Record;

b. valid vessel navigation permit throughout the duration of the authorization; ${ }^{25}$

c. positive assessment by the competent authorities that the vessel, including its master, crew, owner and operator, and charterer if applicable, can comply with the terms and conditions of the authorization, ${ }^{26}$ and with the applicable measures; ${ }^{27}$

d. positive assessment by the competent authorities regarding the vessel's and authorization holder's history of compliance; and

e. payment of fees to the National Public Treasury?

Do the conditions under which an authorization can be issued include:

191

a. fishing and related logbook keeping;

b. navigational equipment to ensure compliance with boundaries and restricted areas, for instance;

c. a tamper-proof VMS, functioning according to binding technical specifications;

25 Or automatic suspension of the validity of the fishing or fishing related activities authorization if the vessel loses the navigation permit.

${ }^{26}$ For instance, the vessel gear is compatible with the requirements in terms of impacts on juveniles, or the master and crew can fulfil reporting obligations in the official language required, etc.

${ }^{27}$ Including applicable international conventions and national laws and regulations in relation to maritime safety, protections of the marine environment, and CMMs or provisions adopted at a national, regional or global level. 
Continuing "Do the conditions under which..."

d. catch recording and timely reporting conditions on catch, effort, discards, fishing location, date and time fished, etc.;

e. marking of fishing gear in accordance with internationally recognized standards, such as the 2019 FAO Voluntary Guidelines for the Marking of Fishing Gear;

191

f. transshipment conditions where applicable, such as authorization request and reporting, ${ }_{2}^{28}$

g. observer coverage if applicable;

$h$. for vessels engaged in fishing related activities, the prohibition to grant services to, or engage with, vessels engaged in IUU fishing activities; and

i. where applicable, the obligation to comply with other State laws and regulations as well as with subregional, regional or global measures?

Does your legal authorization regime require the following information, enabling the identification of accountable persons, areas and species, to be reflected in the authorization itself:

192

a. name of the vessel;

b. IMO number if eligible, the same as the Unique Vessel Identifier in the FAO Global Record;

c. natural or legal person authorized to engage in fishing and fishing related activities;

d. the areas, scope and duration of the authorization; and

e. the species, fishing gear authorized, and other applicable CMMs?

193 Does the authorization get cancelled when the vessel is deregistered?

Do you allow your flagged vessels to operate in areas under the jurisdiction and control of a State only when your competent authorities and those of the coastal State are satisfied that such activities will not undermine the sustainability of living marine resources within the jurisdiction of that coastal State?

195 Is it an obligation for your flagged vessels to comply with the laws and regulations of coastal States?

Do you promote the development of appropriate standards and guidelines which would lead to the more efficient use of energy in harvesting and post-harvest activities within your fleet?

Do you encourage owners, charterers and managers of vessels to fit energy optimization devices to their vessels, as well as equipment to reduce the emission of ozone-depleting substances?

28 Including date and location, weight by species and catch area, name, registration, flag and other relevant information related to the vessels involved in the transshipment to ensure its legality, as well as the port of landing of the transshipped catch. 
Monitoring, control and surveillance (MCS)

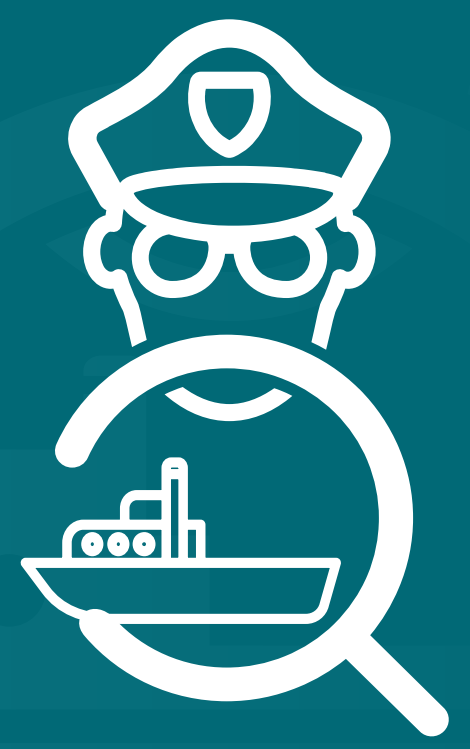


Does your legal framework include an effective MCS system for fishing and fishing related activities to ensure compliance with your CMMs, as well as those adopted by RFMOs?

Does the scope of your MCS system apply to all your flagged vessels in areas under your

199 jurisdiction and beyond wherever they operate, including ports of other State, where applicable?

Does the scope of your MCS system apply to all fishing and fishing related activities at sea and on land?

201 Does the scope of your MCS system apply to all natural and legal persons under your jurisdiction?

202

Have you clearly determined all relevant authorities and their roles and responsibilities within the MCS system?

Are these authorities protected, empowered and accountable in the exercise of their MCS responsibilities?

Do MCS institutions have the staff and budget proportionate to the size of your flagged fishing and fishing related fleet?

Do MCS authorities acquire, store and exchange MCS relevant data and information as required (with due regard for appropriate confidentiality requirements)?

Do MCS authorities have access to the up-to-date registry of vessels?

207 Do MCS authorities regularly check the FAO Global Record?

Do MCS authorities regularly, and in a timely manner, exchange information with other States,

208 RFMOs, FAO and other relevant international organizations in line with PSMA requirements for flag States? ${ }^{29}$

209 Do MCS authorities use international standards in the exchange of information, including the ones in Annex D of the PSMA ("Information systems on port State measures")?

Do MCS authorities have access to relevant information under the competence of other agencies such as maritime, customs, port, health, navy, etc.?

211 Have you adopted a national (and regional if applicable) Plan of Control and Inspection, based on risk analysis, to ensure proper implementation and compliance with applicable CMMs? 
213

Have you adopted SOPs and handbooks for the different actions to be carried out under the National Plan of Control and Inspection?

Do you have a 24/7 operational FMC in place, which receives VMS signal from tamper-proof devices installed in all your flagged vessels wherever they operate, as well as from the flagged vessels of other States operating in areas under your jurisdiction, or other information technology monitoring solutions for small vessels, artisanal fleet and subsistence vessels?

215 Have you established a legally binding time frequency with which vessel transponders shall transmit VMS signals such as position, speed, etc.?

216 Are tracking records and reports from the FMC legally acceptable evidence in administrative and criminal procedures?

Are vessels masters obliged to use other means to transmit their position and speed in case of

217 VMS failure? If so, do you consider as reasonable the duration of the use of other means before the failure must be addressed?

218 Are vessels not transmitting VMS signal obliged to go to a port when the system cannot be fixed at sea?

219 Have you adopted and implemented SOPs and handbooks for staff in the FMC?

220 Is the staff at the FMC properly trained in risk assessment and able to identify suspicious patterns, encounters, possible IUU operations, etc.?

Does the staff at the FMC have access to all relevant data and information on the vessels such as registration, fishing or fishing related authorizations, previous inspection reports, vessels ranked by risk, etc.?

222 Have you attributed legal authority to your competent authorities to take control of the vessels, including denial of sailing or recall to port?

Have you established mandatory requirements regarding fisheries related data that must be recorded and reported in a timely manner by the vessels/masters/operators, such as for logbooks, catches, effort, bycatches and discards, storage plans, landing declarations, transshipments, sales notes, etc.? ${ }^{30}$

224 Have you established the frequency for that mandatory data transmission, and how, by whom and to whom it will be transmitted?

Do you have any other tools in place to ensure proper MCS of your fleet wherever they 
Do you have national or regional observer programmes in place to monitor and verify the reported catch of target and non-target species?

227 Have you clearly defined the objectives and tasks of the observer on board as well as established effective measures to ensure their safety?

228 Have you established how mandatory observer reports are to be transmitted, and the frequency of their transmission?

229 Is the observer report legally acceptable evidence in administrative and criminal proceedings?

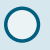

230 Do you encourage your flagged vessels to land, transship or use other port services only in PSMA designated and compliant ports?

Do you have risk-based inspection schemes in place, including SOPs and handbooks, for fishing and fishing related vessels at port, including private ports, and at sea?

232 Have you established benchmarks in inspection schemes? ? $^{31}$

233 Is the vessel port inspection procedure in line with Annex B ("Port State inspection procedures") of the PSMA? ${ }^{32}$

234 Is the content of the inspection report in line with Annex C ("Report of the results of the inspection") of the PSMA?

Have you established minimum training requirements for all staff involved in MCS activities, including those described for port State inspectors in Annex E ("Guidelines for the training of inspectors") of the PSMA?

Is it an obligation for masters and crews on vessels and operators of fishing and fishing related activities to cooperate during inspections and produce all documents as required by the inspector or competent authority on vessel position, catches, fishing gear, fishing operations and related activities? ${ }^{33}$

237 Are the inspection reports of other States legally acceptable evidence in administrative and criminal proceedings? other States and RFMOs?

${ }^{31}$ Including information available from catch, landing and transshipment reports, aggregated according to areas and species, in a full, timely and regular manner, taking into account applicable confidentiality requirements.

32 As specified in Annex B, relevant documentation also include documents pursuant to the Convention on International Trade in Endangered Species of Wild Fauna and Flora.

33 Including in cases of inspections carried out at ports and boardings at sea by another State's duly authorized inspectors, whether under RFMOs or other applicable arrangements. 
Do you implement internationally agreed MCS measures, adopted in the framework of a

239 competent RFMO and consistent with international law, to deter the activities of vessels flying the flag of non-cooperating non-contracting parties to that RFMO/arrangement and which engage in activities undermining the effectiveness of the international CMMs of that RFMO?

240 Do you carry out awareness-raising campaigns addressed to the industry to promote compliance and a better understanding of the MCS requirements?

241

Do you promote the knowledge and understanding of MCS issues within national judicial and administrative systems? 
3.6 Enforcement

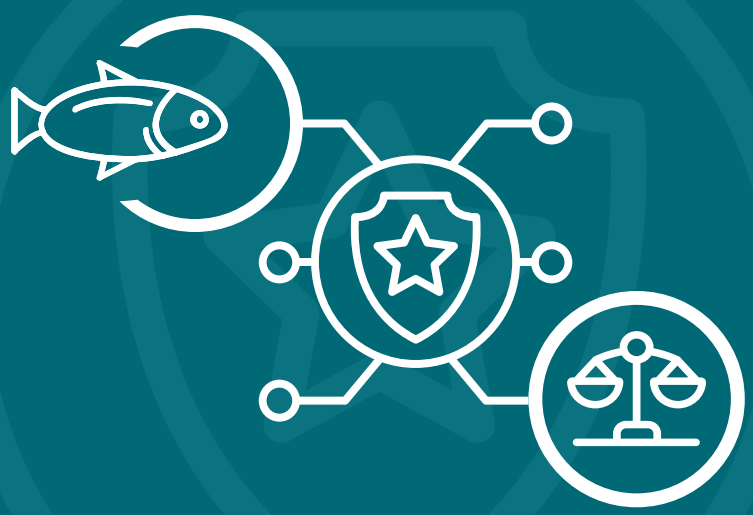


Does your legal framework include a proportionate and effective enforcement regime to deter, and respond to, violations of your CMMs regarding fishing and fishing related activities, as well as those adopted by competent RFMOs?

Does your legal framework clearly define what actions or omissions will be considered as a violation?

Does your legal framework establish which of those violations will be considered as serious, including: falsifying the markings, identity or registration of a vessel; operating without a vessel navigation permit or authorization; operating in violation of the conditions set in the authorization; not accurately recording, not reporting or seriously misreporting catch or catch-related data; obstructing, concealing, tampering with or disposing of evidence relating to an investigation; committing several non-serious violations; and other violations considered serious under competent RFMOs, etc.?

245 Does your legal framework clearly establish who is to be accountable for any violation, including owner, beneficial owner, operator, charterer, master, etc.?

246 Do you have the capacity to detect and take enforcement action with respect to violations?

247 Do you have the authority and capacity to conduct timely investigations of violations, including the establishment of the identity of the offenders and the nature of the violations?

Does your legal framework include the obligation to investigate and, if appropriate, take necessary action, upon the receipt of a report from a State or an RFMO with clear grounds that proper jurisdiction and control have not been exercised over your flagged vessel or that it has been identified as participating in IUU fishing, or fishing related activities in support of such fishing?

Do you have an appropriate system in place for the diligent acquisition, collection,

249 preservation of evidence and the maintenance of its integrity, including by making it available to enforcement authorities of other States and, if applicable, to RFMOs?

Do you have an administrative or criminal legal system in place to ensure that procedures to apply sanctions are initiated in a timely and effective manner against those who act in contravention of your legal framework?

Do you, in your legal framework, have a regime of sanctions proportionate to the seriousness of the violation, depriving offenders of benefits accruing from their illegal activities and effective in securing compliance and discouraging violations wherever they occur?

Does your sanction regime include the refusal, suspension or withdrawal of vessel authorizations as a result of serious violations?

Does your sanction regime include the refusal, suspension or withdrawal of economic incentives, including subsidies, for legal or natural persons and vessels that have committed violations?

Does your sanction regime include the prohibition of high seas fishing and fishing related activities by a vessel flying your flag where such vessel has been involved in the commission of a serious violation, until such time that the outstanding sanctions imposed have been complied with? 
Does your sanction regime include provisions which may permit, inter alia, the refusal, withdrawal or suspension of authorizations to serve as masters or officers of a vessel, where such masters or officers hold national authorizations?

Does your enforcement scheme establish specific sanctions for those who obstruct the task of the duly authorized inspectors, observers, authorized persons or officials of other competent authorities?

257 Does your enforcement scheme establish specific sanctions for those competent authorities who do not carry out their duties with due diligence?

$258 \begin{aligned} & \text { Is your enforcement scheme capable of ensuring that sanctions are complied with including, } \\ & \text { where appropriate, preventing the vessel and the natural or legal person from engaging in } \\ & \text { fishing or fishing related activities while proceedings take place and after sanctions have been } \\ & \text { complied with? }\end{aligned}$

Does your enforcement scheme grant the power to your competent authorities to impose immediate enforcement measures such as detention, confiscation, denial of the use of port services, or any other measure needed to ensure that products derived from suspected IUU fishing do not reach the market while the investigation is ongoing?

Does your sanction regime establish specific and more severe sanctions in cases of repeated offences?

Does your enforcement scheme establish the obligation for your competent authorities to engage in cooperation and mutual legal assistance including, as appropriate, the sharing of information and reporting arrangements with other States and international organizations including RFMOs, as well as the timeliness of action following requests for assistance?

Do you implement effective and timely sanctions in response to requests from other States or, if applicable, RFMOs to take measures in respect of vessels flying your flag?

Do you contribute to the establishment of regional schemes for cooperation, with other States and RFMOs, in the enforcement of applicable measures with respect to fishing operations and fishing related activities?

Do you contribute to the implementation, with other States and RFMOs, of joint enforcement efforts of the measures applicable with respect to fishing operations and fishing related activities?

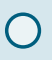

Where you are implementing an enforcement scheme and where enforcement actions by flag States are agreed under an RFMO, do you ensure that adequate and timely peaceful mechanisms to resolve disputes in respect of those actions exist within relevant RFMOs?

Have you implemented internationally agreed enforcement measures, adopted in the framework of a competent RFMO and consistent with international law, to deter the activities of vessels flying the flag of non-cooperating non-contracting parties to that RFMO/arrangement that engage in activities which undermine the effectiveness of CMMs of such RFMO?

Have you made arrangements individually, together with other States, or with the appropriate international organization, to integrate fishing operations into maritime search and rescue systems? 


\section{Port State responsibilities}

The questions in this Chapter are designed to guide port States to exercise jurisdiction and control over vessels that enter and use ports to ensure that such vessels subjected to port State jurisdiction comply with measures established in accordance with international law and have not supported or engaged in IUU fishing and related activities in support of such fishing. 
Does your legal framework contain a clear set of definitions that ensures terms are used consistent with the PSMA, ${ }^{34}$ such as "vessel" "fishing" or "fishing related activities"? 35

Does your legislative framework expressly apply to:

a. all vessels not entitled to fly your flag, ${ }^{36}$ whether carrying fish or not, including stateless vessels, container vessels, ${ }^{37}$ and chartered vessels, ${ }^{38}$ which seek entry to your ports or are in one of your ports;

b. all areas under your jurisdiction, including all ports (public and private); and

c. all persons, natural or legal?

b. al a a underyour juisdicion, including al ports (public and privatel: and

Have you conducted an analysis of which of your ports are visited by foreign vessels, including the number of vessels per year, and in which ports?

271 Have you designated and publicized the ports to which foreign vessels shall request entry?

272 Have you uploaded the list of designated ports in the FAO PSMA Applications for Designated Ports and Contact Points (FAO Designated Ports Application)? ${ }^{39}$ support of such fishing?

${ }^{34}$ References in this document to "legal framework" include not only fisheries specific laws and regulations but also other relevant legal texts, such as those related to the registration of vessels.

35 For these purposes, vessel means: any vessel, ship of another type or boat used for, equipped to be used for, or intended to be used for: a) searching for, attracting, locating, catching, taking or harvesting fish or any activity which can reasonably be expected to result in the attracting, locating, catching, taking or harvesting of fish; or b) any operation in support of, or in preparation for, fishing, including the landing, packaging, processing, transshipping or transporting of fish that has not been previously landed at a port, as well as the provisioning of personnel, fuel, gear and other supplies at sea.

${ }^{36}$ Including flagged vessels to non-parties to the PSMA, as long as the measures applied to them are fair, nondiscriminatory, transparent, and consistent with the PSMA and other applicable international law, and they aim to deter the activities of those non-parties which undermine the effective implementation of the PSMA.

${ }^{37}$ Container vessels shall be included when they are carrying fish that has not been previously landed, or even if previously landed, to clarify when there are clear grounds for suspecting that such vessels have engaged in fishing related activities in support of IUU fishing.

${ }^{38}$ Vessels chartered by your country exclusively for fishing in areas under your national jurisdiction, and operating under your country's authority, may be subject to different measures than other foreign vessels only when the measures applied to the chartered vessels are as effective (in preventing, deterring and eliminating IUU fishing and fishing related activities in support of such fishing) as the ones applied to vessels flying your flag.

${ }^{39}$ The application can be accessed at www.fao.org/fishery/port-state-measures/psmaapp/ 
Have you appointed a contact point for PSMA purposes, in particular, for the exchange of information, and uploaded it to the FAO Designated Ports Application?

Have you ensured enough capacity to conduct inspections, in line with the PSMA, in designated ports?

Does your legal framework require vessels of other States to submit an advance request for entry into port (AREP)? If so:

a. Have you established a timeframe within which such AREP is provided sufficiently in advance, so that it can be processed and a decision can be made prior to the vessel's arrival?

b. Do you require at least the information in Annex A ("Information to be provided in advance by vessels requesting port entry") of the PSMA to be provided in advance by the vessel requesting port entry?

c. Have you established a standardized procedure, with the intervention of all relevant authorities, and with clear roles and responsibilities for each of them, in the process of determining whether vessels requesting port entry have engaged in IUU fishing or fishing related activities in support of such fishing?

d. Does this method/procedure include a risk assessment?

e. Does this method/procedure include the compulsory consultation of data/information sources such as the FAO Global Record?

f. Do you cross-check the information received by competent authorities and agencies such as fisheries, customs, port, navy, maritime, health, immigration, police agencies, etc.?

g. If needed, do you cross-check the information received with competent authorities of another State and RFMOs?

h. Have you established and maintained up-to-date, integrated databases to be able to fulfill your obligations under the PSMA?

i. Is the AREP an electronic process?

In the case of authorization of entry, are your competent authorities obliged to:

a. communicate such decision to the vessel or its representative; and

b. issue a written authorization to be presented by the master of the vessel or the vessel's representative upon the vessel's arrival at the port? 
In cases where there is sufficient proof that a vessel seeking entry into your ports has engaged in IUU fishing or fishing related activities in support of such fishing: ${ }^{40}$

a. Have you established a standardized procedure on what steps to follow in this case, with the intervention of all relevant authorities, with clear roles and responsibilities for each of them in this process?

b. Are your competent authorities obliged to either deny port entry or allow port entry exclusively for the purpose of inspecting the vessel and taking actions which are at least as effective as denial of port entry in preventing, deterring and eliminating IUU fishing and fishing related activities in support of such fishing?

c. Are your competent authorities obliged to communicate their decision to the vessel or its representative?

d. Are your competent authorities obliged to communicate the decision of denial of port entry to the flag State, relevant coastal States, RFMOs and other international organizations?

e. Are your competent authorities obliged to deny such vessel the use of the port for landing, transshipping, packaging and processing of fish and for other port services, including refueling and resupplying, maintenance and drydocking?

f. Are your competent authorities obliged to allow entry into port for reasons of force majeure or distress, and to ensure that the vessel only receives relevant assistance?

Where a vessel has entered one of your ports, are your competent authorities obliged to deny a vessel the use of the port for landing, transshipping, packaging and processing of fish and for other port services, including refueling and resupplying, maintenance and drydocking, in the following cases:

a. if you find that the vessel does not have a valid and applicable authorization to engage in fishing or fishing related activities required by its flag State, or as required by a coastal State in respect of areas under the national jurisdiction of that State;

b. if you receive clear evidence that the fish on board was taken in contravention of the applicable requirements of a coastal State in respect of areas under the national jurisdiction of that State;

c. if the flag State does not confirm within a reasonable period of time, on your request, the legality of origin of the fish on board; and

d. if you have reasonable grounds to believe that the vessel was engaged in IUU fishing or fishing related activities in support of such fishing ? $^{41}$

When your competent authorities deny the use of port to a vessel, are they obliged to allow

281 that vessel to use port services that are proven to be essential to the safety or health of the crew or the vessel itself or, where appropriate, for the scrapping of the vessel?

${ }^{40}$ In particular, the inclusion of a vessel on a list of vessels having engaged in such fishing or fishing related activities adopted by a relevant RFMO in accordance with the rules and procedures of such organization and in conformity with international law.

41 Unless the vessel can establish that it was acting in a manner consistent with relevant CMMs or the vessel was provisioning personnel, fuel, gear and other supplies at sea to an IUU vessel before the engagement by the latter in IUU fishing activities. 
Are your competent authorities obliged to promptly notify the denial of the use of the port, or the withdrawal of that denial to the flag State (where there is sufficient proof that the grounds on which the use was denied were inadequate or erroneous, or that such grounds no longer apply) and, as appropriate, relevant coastal States, RFMOs and other international organizations?

Have you developed a National Plan of Control and Inspection or any other instrument with thresholds applicable to designated port, fisheries, type of vessels, etc., to ensure an annual level of inspections sufficient to achieve the objective of the PSMA?

284 Have you developed a risk-analysis matrix to ensure effective prioritization in the determination of which vessels to inspect?

In determining which vessel to inspect, are your authorities obliged to give priority to:

a. vessels that have been denied entry or use of a port;

b. vessels upon request by other States or RFMOs; and

c. other vessels, upon clear grounds for suspecting that they have engaged in IUU fishing activities or fishing related activities in support of such fishing?

Have you supported the adoption of decisions in RFMOs or FAO to establish minimum levels for inspection?

287 Have you designated in your legislation the inspecting agency or agencies and the lead agency?

Have you established a standardized procedure, with the intervention of all relevant authorities in different competent agencies, with clear roles and responsibilities for each of them, in the process of determining whether vessels in your ports have engaged in IUU fishing or fishing related activities in support of such fishing?

289 Have you established clear SOPs to ensure that proper actions are being carried out in line with PSMA requirements?

290 Are your inspectors obliged, as a minimum, to carry out their functions in line with the port State inspection procedures stated by Annex B ("Port State inspection procedures") of the PSMA? ${ }^{42}$

291 Are your inspectors properly trained in line with the guidelines set out in Annex E ("Guidelines for the training of inspectors") of the PSMA?

292 Does your legislation require that inspections are only carried out by properly qualified inspectors authorized and empowered for that purpose?

293 Are your inspectors obliged to present an appropriate document identifying themselves as inspectors to the master of the vessel, prior to an inspection?

42 As specified in Annex B, relevant documentation also includes documents pursuant to the Convention on International Trade in Endangered Species of Wild Fauna and Flora. 
Is it clear in your legislation that inspectors shall examine, and masters shall allow access to, all relevant areas of the vessel, the fish on board, the nets and any other gear, equipment, and any document or record on board that is relevant to verify compliance with relevant CMMs?

295 Is it clear in your legislation that masters shall give inspectors all necessary assistance and information, and present relevant material and documents as may be required?

Do you have measures in place to ensure that inspections are conducted in a fair, transparent its master or $\mathrm{crew}$ ? $^{43}$

297 Do you have any arrangements in place to invite any flag State to participate in an inspection?

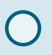

Are your inspectors obliged to submit an inspection report containing, as minimum standard, the information set out in Annex C ("Report of the results of the inspection") of the PSMA?

299 Are your competent authorities obliged to transmit the results of each inspection to the flag State of the inspected vessel?

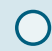

Are your competent authorities obliged to transmit the results of the inspection of a vessel, based on sufficient evidence, to: coastal States in whose sovereign or jurisdictional waters the vessel engaged in IUU fishing, or fishing related activities in support of such fishing; State of which the vessel's master is a national; relevant RFMOs; FAO and other international organizations?

Have you established a communication mechanism that allows for direct electronic exchange of information, either bilaterally, regionally or both (with due regard for appropriate confidentiality requirements)?

Are you handling the information related to PSMA according to the codes and guidelines set out in Annex D ("Information systems on port State measures") of the PSMA?

If, following an inspection, you find clear grounds for believing that the vessel has engaged in IUU fishing or fishing related activities in support of such fishing, are your competent authorities obliged to:

a. promptly notify the flag State and, where appropriate, the coastal States, RFMOs and other international organizations, as well as the master's State of nationality?

b. deny the vessel the use of the port, except for essential port services for the safety or health of the crew or the safety of the vessel?

43 Such as: making all possible efforts to avoid unduly delaying the vessel, to minimize interference and inconvenience, including any unnecessary presence of inspectors on board, and to avoid action that would adversely affect the quality of the fish on board; making all possible efforts to facilitate communication with the master or senior crew members of the vessel, including where possible and where needed, that an interpreter accompanies the inspector; not interfering with the master's ability, in conformity with international law, to communicate with the authorities of the flag State. 
Does your legislation include the following possible violations arising from the PSMA:

a. not requesting advance port entry;

b. submitting false information;

c. entering into/using a non-designated port;

d. not presenting the authorization of entry upon arrival at port;

e. entering a port or using the port services when previously denied;

f. obstructing or refusing to provide the necessary assistance and information during an inspection;

g. supporting IUU fishing by supply vessels; and

h. causing IUU fishing products to enter into the market?

Does your legislation include sanctions of adequate severity, which may have a deterrent effect for the aforementioned violations?

Have you updated your legislation to include the duties for your competent authorities derived from the PSMA?

Do you have appropriate legislation in place to ensure that proper enforcement action is taken against vessels, persons or organizations that use, or allow to be used, ports where such use has been denied?

Do you have appropriate legislation in place to ensure that proper enforcement (administrative and criminal proceedings) is carried out following the identification of a violation, including arresting, seizing, detaining or exercising any other lawful authority?

Does your legislation clearly define which elements can constitute evidence - for instance, the VMS tracking of the vessel - and shall be protected by the chain of custody under the investigation of a presumed violation?

Do you have a robust sanctioning regime as part of your legislation (administrative and criminal penalties) that is of sufficient severity to be effective in securing compliance and to discourage violations wherever they occur, as well as to deprive offenders of the benefits accruing from their illegal activities?

311 Do you have a process in place to maintain the relevant information on recourse available to the public in accordance with the PSMA?

Are your competent authorities obliged, upon written request, to provide to the owner, well as to inform them of the outcome of such recourse? 
313 When authorities other than the flag State's, such as those of an RFMO or coastal State, have obliged to inform them of any change in those decisions?

\begin{tabular}{|c|c|}
\hline 314 & $\begin{array}{l}\text { Does your legislation allow for taking additional or more stringent measures that are in } \\
\text { conformity with international law than those measures specifically set out under the PSMA } \\
\text { where there are clear grounds for believing that a vessel has engaged in IUU fishing or fishing } \\
\text { related activities in support of such fishing? }\end{array}$ \\
\hline
\end{tabular}

315

Are the binding port State measures applicable to your flagged vessels at least as effective in preventing, deterring and eliminating IUU fishing and fishing related activities in support of such fishing as those applied to foreign vessels? 


\section{References}

CITES. 1973. Convention on International Trade in Endangered Species of Wild Fauna and Flora. Geneva, Switzerland. (also available at cites.org/sites/default/ files/eng/disc/CITES-Convention-EN.pdf).

FAO. 1993. Agreement to Promote Compliance with International Conservation and Management Measures by Fishing Vessels on the High Seas [online]. FAO Conference. Twenty-seventh Session, November 1993 through Resolution 15/93. [Cited 11 December 2020]. www.fao.org/fileadmin/user upload/legal/ docs/012s-e.pdf.

FAO. 1995. Code of Conduct for Responsible Fisheries. Rome, FAO. 41 pp. (also available at www.fao.org/3/v9878e/V9878E.pdf).

FAO. 2001. International Plan of Action to prevent, deter and eliminate illegal, unreported and unregulated fishing. Rome, FAO. 24 pp. (also available at www.fao.org/3/y1224e/Y1224E.pdf).

FAO. 2010. Agreement on Port State Measures to Prevent, Deter and Eliminate Illegal, Unreported and Unregulated Fishing. Accord relatif aux mesures du ressort de l'État du port visant à prévenir, contrecarrer et éliminer la pêche illicite, non déclarée et non réglementée. Acuerdo sobre medidas del Estado rector del puerto destinadas a prevenir, desalentar y eliminar la pesca ilegal, no declarada y no reglamentada. Rome/Roma, FAO. 100 pp. (also available at www.fao.org/3/a-i1644t.pdf).

FAO. 2015. Voluntary Guidelines for Flag State Performance. Directives volontaires pour la conduite de l'État du pavillon. Directrices Voluntarias para la Actuación del Estado del Pabellón. Rome/Roma. 53 pp. (also available at www.fao.org/3/14577T/i4577t.pdf).

FAO. 2019. Voluntary Guidelines on the Marking of Fishing Gear. Directives volontaires sur le marquage des engins de pêche. Directrices voluntarias sobre el marcado de las artes de pesca. Rome/Roma. 88 pp. (also available at www.fao.org/3/ca3546t/ca3546t.pdf).

International Labour Organization (ILO). 1987. Repatriation of Seafarers Convention (C166) (Revised) [online]. Geneva, Switzerland. [Cited 21 December 2020]. ilo.org/dyn/normlex/en/f?p=NORMLEXPUB:12100:0::NO::P12100 INSTRUMENT ID:312311).

International Labour Organization (ILO). 2007. Work in Fishing Convention (No. 188) [online]. Geneva, Switzerland. [Cited 21 December 2020]. ilo.org/dyn/ normlex/en/f?p=NORMLEXPUB:12100:0::NO::P12100 ILO CODE:C188).

International Maritime Organization (IMO). 1965. Convention on Facilitation of International Maritime Traffic (FAL). London, UK. (also available at www.imo. org/en/About/Conventions/Pages/Convention-on-Facilitation-of-InternationalMaritime-Traffic-(FAL).aspx). 
International Maritime Organization (IMO). 1973. International Convention for the Prevention of Pollution from Ships (MARPOL), as modified by the Protocol of 1978 relating thereto and by the Protocol of 1997. London, UK.

International Maritime Organization (IMO). 2018. Cape Town Agreement of 2012 (2018 Edition). London, UK.

United Nations (UN). 1982. United Nations Convention on the Law of the Sea. New York. (also available at www.un.org/depts/los/convention agreements/ texts/unclos/unclos e.pdf).

United Nations (UN). 1995. Agreement for the Implementation of the Provisions of United Nations Convention on the Law of the Sea of 10 December 1982 relating to the Conservation and Management of Straddling Fish Stocks and Highly Migratory Fish Stocks. New York. (also available at https://www.un.org/ Depts/los/convention agreements/convention overview fish stocks.htm). 



CHECKLISTS AND TECHNICAL

GUIDELINES TO COMBAT ILLEGAL, UNREPORTED AND UNREGULATED

(IUU) FISHING

Volume I: a consolidated checklist

of coastal, flag and port State

responsibilities to combat illegal,

unreported and unregulated (IUU) fishing

Illegal, unreported, and unregulated (IUU)

fishing remains one of the greatest threats to marine ecosystems, and undermines national and regional efforts to achieve sustainable fisheries. A framework of binding and voluntary international instruments has been developed over recent decades, which collectively outline the responsibilities of coastal, flag and port States to prevent, deter and eliminate IUU fishing.

The purpose of this document is to consolidate these responsibilities within a single reference document. The responsibilities are presented as a checklist, in questionnaire format.

The document aims to serve both as a reference document for professionals as well as an assessment tool for practitioners. 